\section{6 (9 \\ OPEN ACCESS}

'Division of Pulmonary Medicine, National Hospital Organization Kochi Hospital, Kochi, Japan

2Department of Clinical Investigation, National Hospital Organization Kochi Hospital, Kochi, Japan

${ }^{3}$ Division of Pathology, National Hospital Organization Kochi Hospital, Kochi, Japan

\section{Correspondence to} Dr Tsutomu Shinohara, Department of Clinical Investigation, National Hospital Organization National Kochi Hospital, 1-2-25 Asakuranishimachi,Kochi 7808077, Japan; shinoharat@ kochi2.hosp.go.jp

Received 14 September 2016 Accepted 2 October 2016 Published Online First 25 October 2016

\title{
Cavitary lung cancer with cartilage tissues in the wall mimicking aspergilloma
}

\author{
Takashige Taoka, ${ }_{1}^{1}$ Tsutomu Shinohara, ${ }^{2}$ Keishi Naruse, ${ }^{3}$ Fumitaka Ogushi ${ }^{1}$
}

\section{DESCRIPTION}

A 65-year-old female presented with a cavitary lesion in the right upper lung field (figure 1A). The diagnosis was aspergilloma because of the chest CT appearance of a fungus ball-like mass in the cavity (figure 1B) and treatment was started with itraconazole $(200 \mathrm{mg} /$ day $)$. However, the cavitary lesion enlarged over a period of 6 months (figure 1C), with a C-reactive protein (CRP) level under $0.5 \mathrm{mg} / \mathrm{dL}$. The patient was referred to our hospital and microscopic examination of a transbronchial lung biopsy of the cavitary lesion revealed lung cancer. A right upper lobectomy was performed. Histologically, pleomorphic carcinoma, confirmed by immunohistochemical staining, proliferated in a polypoid manner from the wall of the cavity, which consisted of malignant cells and cartilage tissues (figure 2A, B). There was no evidence of fungal elements. After surgery, the serum carcinoembryonic antigenlevel went down from $8.4(<5.0)$ to $2.4 \mathrm{ng} / \mathrm{mL}$.
A primary lung cancer has been considered to manifest a cavitary lesion in three ways: (1) cavitary necrosis of the primary tumour itself, (2) abscess formation of the lung parenchyma distal to bronchial obstruction by the tumour and (3) secondary carcinomatous abscesses induced by infected tumour emboli from the primary tumour. ${ }^{1}$ These pathophysiologies are usually accompanied by high levels of inflammatory markers reflecting breakdown of the tissue. A case of cavitary lung cancer with a fungus ball-like mass, which is extremely rare, ${ }^{2}{ }^{3}$ manifested high levels of CRP. ${ }^{2}$ Interestingly, the wall of the cavity, but not the polypoid mass, in our patient included cartilage tissues, suggesting that the wall was derived from the bronchial wall, which was diffusely replaced by tumour cells later and probably enlarged by a check valve mechanism without breakdown of the tissue.

Although a fungus ball-like shadow suggests a pulmonary aspergilloma, comprehensive examinations
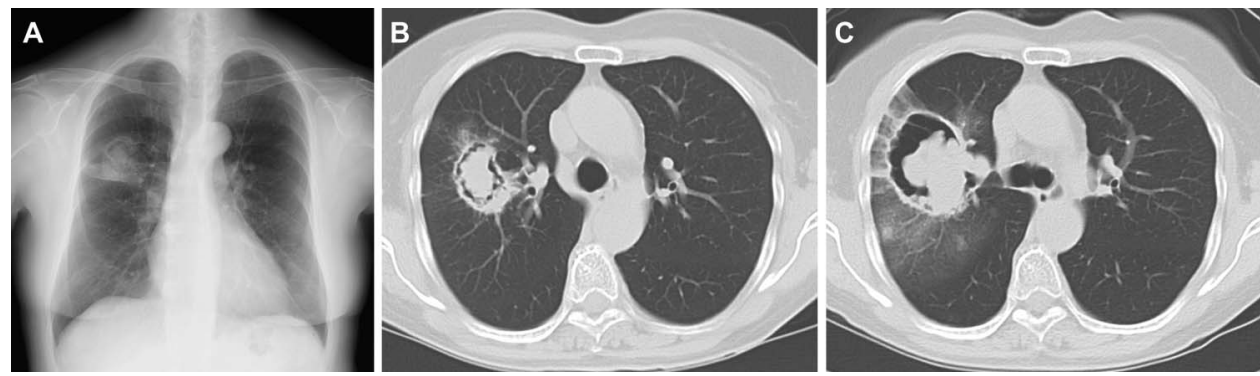

Figure 1 Chest X-ray (A) and CT (B and C) before (A and B) and after (C) treatment with itraconazole for 6 months. $A$ fungus ball-like mass was observed in the cavity $(A-C)$. The cavitary lesion enlarged despite the treatment $(C)$.
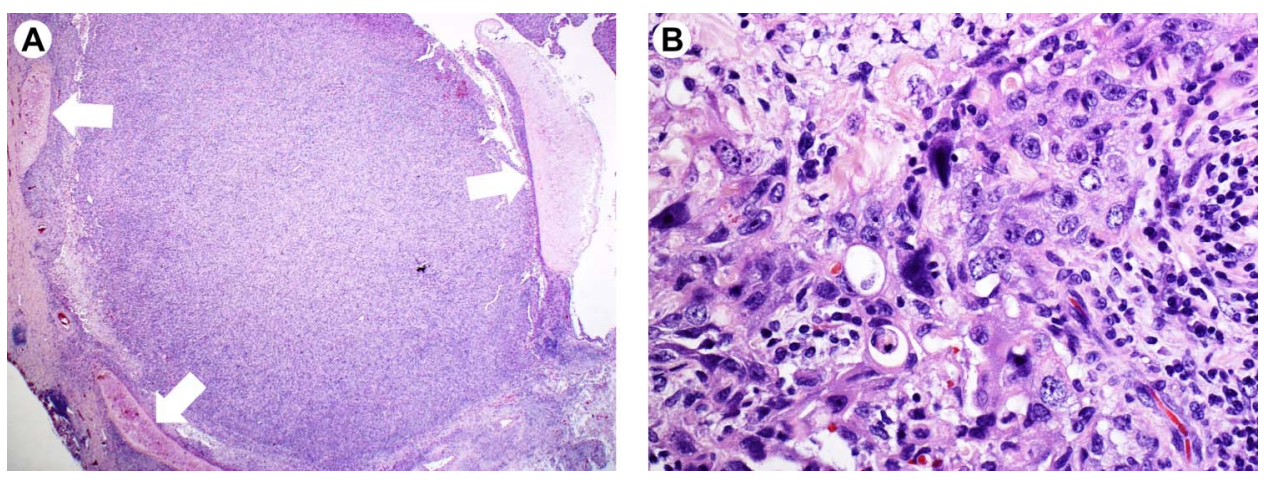

Figure 2 Histology of a resected specimen. Pleomorphic carcinoma proliferated in a polypoid manner from the wall of the cavity, which consisted of malignant cells and cartilage tissues (arrows) (A) and undifferentiated malignant cells without distinct architectural features (B). 
including endoscopy for a differential diagnosis of lung cancer should always be considered, regardless of inflammatory marker levels.

Contributors Conception and design: TT, TS. Collection and interpretation of data: TT, TS, KN, FO. Drafting of the manuscript: TT, TS. Approval of the final version of the manuscript: TT, TS, KN, FO.

Competing interests None.

Patient consent Obtained.

Provenance and peer review Not commissioned; externally peer reviewed.
Open Access This is an Open Access article distributed in accordance with the Creative Commons Attribution Non Commercial (CC BY-NC 4.0) license, which permits others to distribute, remix, adapt, build upon this work non-commercially, and license their derivative works on different terms, provided the original work is properly cited and the use is non-commercial. See: http://creativecommons.org/ licenses/by-nc/4.0/

\section{REFERENCES}

1 Chaudhuri MR. Primary pulmonary cavitating carcinomas. Thorax 1973;28:354-66.

2 Bandoh S, Fujita J, Fukunaga Y, et al. Cavitary lung cancer with an aspergilloma-like shadow. Lung Cancer 1999;26:195-8.

3 Goto T, Kato R, Maeshima A, et al. Cavitary lung cancer with an aspergilloma-like shadow. J Thorac Oncol 2010;5:580-1. 